\title{
Yoga for Lumbo-Pelvic Stability and Function in Women's' Health -Need for Combined Approach with Physiotherapy
}

\author{
Nilima Bedekar* \\ Department of Musculoskeletal Sciences, College of Physiotherapy, India
}

Submission: September 03, 2019; Published: September 19, 2019

*Corresponding author: Nilima Bedekar, Department of Musculoskeletal Sciences, Sancheti Institute, College of Physiotherapy, Pune, India

\section{Abstract}

Yoga is known for health benefits in health and diseases. Effects of Yoga for Lumbo-pelvic stability and function in Women's' Health are relatively recent. Physiotherapists have training and expertise in evaluation of lumbo-pelvic dysfunction. However, lagging in making better impact. A combined approach of Yoga and Physiotherapy has lot of potential for effective management. Pranayam, mulabandh ashwini mudra, ananas with physiotherapy can gain stability and function in women.

Keywords: Pranayama; Bandha; mudra; Surya namaskar; Physical; Mental; Emotional stability; Thyroid gland; Pulmonary capacity; Gaseous exchange; Reduce respiratory rate; Hyperventilation; Kapalbhati pranayama; Ujjai pranayama; Anulom Vilom pranayama; Mula Bandh; Ashwini mudra

\section{Opinion}

Women undergo marked stages of life. Childbearing, menopausal and ageing process leads to stress on abdomen, pelvic structures including muscles, ligaments and bone structure. Physical, mental, emotional stability is the key for health. Yoga components - Pranayama, Bandha and mudra, and series of Yoga asanas, Surya namaskar protocols can be developed for managing pelvic floor dysfunction and core stability. Yoga is philosophy or way of life. There are many paths through one can experience bliss in life, many classifications and schools of yoga are available. There is new knowledge added highlighting yoga as intervention in treating women's' issues. Current literature has holistic/ integrated approach combining physiotherapy and yoga.

Pranayama techniques are encompassing more than pulmonary benefits [1,2]. Anulom Vilom pranayam helps to increase pulmonary capacity, gaseous exchange, reduce respiratory rate / hyperventilation. Ujjai pranayama influences thyroid gland dysfunction. Kapalbhati pranayam has effect on core muscle activation, strength and awareness [3]. It is important to follow correct practice. Forced expiratory movement starts with pelvic floor activation followed by transverses abdominis. muscles during kapalbhati pranayam.

Mula Bandh and ashwini mudra have influenced development of strengthening exercises to pelvic floor. Mula bandh is concentrating or focusing at perineal body and gently activating pelvic floor muscles anterior spincters- vaginal orifice and urinary spincters. Ashwini mudra is contraction of back passage or anal sphinchters. Varied yoga postures for simultaneous activation are described in details by Dr Coulter [4], who received training from Yoga Gurus [4]. Initial books do not have referencing nor published with clinical applications. New developments are recently in publications by various Yoga institutions like Swami Vivekananda Yoga Anusandhana Samsthana (S-VYASA University) Bengaluru, India, Bihar Yoga bharati, Munger, Bihar, India,

Yoga- combines physical practice with mental awareness. Stability has to be gained to control the flexibility and mobility achieved. The beauty of asanas is richness and variety of postures linking all segments of extremities including spine segments. For example: Gomukhasana, ardhamatsyendrasana, ardha-badhakonasana. These have impact on spinal mobility and rotator components which stimulate autonomic function vital for women. There are many ananas mentioned for relieving symptoms of flatulence- example pavanmuktasana. In womens' health domain, combined approach has worked for dysmenorrhea. [5,6] Studies are currently undertaken at Sancheti college of Physiotherapy, Pune India on effects of yoga on menstrual migrane. 
The lumbo-pelvic-hip complex known as lumbar core is a three-dimensional space bounded by Diaphragm (from above), abdominals transversus and oblique muscles (anterior-lateral or front and side), paraspinal, multifidus and gluteal muscles (posterior or back), and pelvic floor including hip girdle (at the bottom). The muscles group activation produces a corset-like stabilization effect on the trunk and spine, giving stable base for the limb movements. Article by Rathore et al. [7] describes in details Anatomical Correlation of Core Muscle Activation in Different Yogic Postures [7]. This will help in planning yogic exercises that challenge the muscle groups without causing loads that may be detrimental to recovery and pain-free movement. A strong and efficient core is necessary for maintaining proper muscle balance throughout the human kinetic system.

$\mathrm{Ni}$ et al. [8] have studied Core muscle function during specific yoga poses using surface Electromyography in 30 healthy yoga practitioners. The conclusions are The High plank, Low plank and Downward facing dog poses are effective for strengthening external oblique abdominis, Chair and Warrior 1 poses for targeting gluteus maximus, and Chair and Halfway lift poses for strengthening longissimus thoracis. And these three muscles could be strengthened by the Upward facing dog pose. Effects of yoga are explained and documented during pregnancy and postnatal recovery $[9,11]$. Effects of mulbandh have been highlighted for management of pelvic organ prolapsed $[11,13]$

Surya namaskar is combination or cyclic transition in various Yogasanas. Surya namaskar has been well studied for improvisation of strength, endurance and body composition. This exercise involves attainment of a series of yogic postures in succession, coordinating with breathing, and has been found to be effective in improving cardiorespiratory functions. It is slow, sustained, repetitive activity utilizing both the aerobic and the anaerobic systems. It includes closed chain activities, even of the upper limbs, which is optimal for osteogenesis. Have found to be effective in controlling weight and function in women. This can influence dysfunction $[13,14]$ and gain health benefits [14].

Combined approach of yoga and physiotherapy need to be developed for womens' health promotion and dysfunction. Pelvic pain and dysfunction include a wide range of conditions from incontinence, pelvic organ prolapse, weak inner core musculature leading to pelvic instability, low back pain during pregnancy and childbearing age, coccyx, sacro-iliac, pubic symphysis derangements. Differential diagnosis will be key for relief of symptoms. Yoga approach as 'Therapy' needs critical evaluation, supervision through sessions as incorrect practice can be detrimental.

\section{References}

1. Deshpande PB (2006) Improve health and reduce healthcare costs from pranayama with six sigma; in association with Louisville Pranayama Group, Louisville, Kentucky, Reflections 5.

2. Muscle Activity during Yoga Breathing Exercise Compared to Abdominal Crunches.

3. Deshmukh S, Bedekar N (2017) Effect of Kapalbhati pranayama on core strength in overweight individuals. International Journal of Yoga, Physiotherapy and Physical Education 2(3): 50-51.

4. Coulter D (2010) Anatomy of Hatha yoga. Motilal banarasidass, New Delhi, India

5. Kulkarni G, Bedekar N (2014) An Experimental Study of Selected Yoga Poses on Young Adult Female Population Reporting Primary Dysmenorrhoea. VIMS Health Sci Journal 1(3): 125-129.

6. Prabhu S, Nagrale S, Shyam A, Sancheti P (2019) Effect of yogasanas on menstrual cramps in young adult females with primary dysmenorrhea. International Journal of Physiotherapy and Research IJPR 7 (4): 31293134.

7. Rathore M, Trivedi S, Abraham J, Sinha MB (2017) Anatomical Correlation of Core Muscle Activation in Different Yogic Postures. Int J Yoga 10(2): 59-66.

8. Ni M, Mooney K, Harriell K, Balachandran A, Signorile J (2014) Core muscle function during specific yoga poses. Complement Ther Med 22(2): 235-43.

9. Ferreira M, Mariana Saavedra M, Santos P (2018) Yoga therapy in pregnancy. Journal of Yoga and Physiotherapy 4(1).

10. Cervone M, Neville C (2018) Mula Bandha and Raising Awareness about Pelvic Floor Dysfunction Journal of Yoga and Physiotherapy 4(5).

11. Sweta KM, Godbole A, Awasthi HH, Pandey U (2018) Effect of Mula Bandha Yoga in Mild Grade Pelvic Organ Prolapse: A Randomized Controlled Trial. Int J Yoga 11(2): 116-121.

12. Jakhotia KA, Shimpi AP, Rairikar SA, Mhendale P, Hatekar R, et al. (2015) Surya namaskar: An equivalent approach towards management of physical fitness in obese females. Int J Yoga 8(1): 27-36.

13. Deshmukh A, Chincholkar S, Sutar A, Ghodey S (2018) A comparative study between Pilates and Surya namaskar on flexibility in women having sedentary lifestyle using sit and reach test and shoulder and wrist test. International Journal of Yoga, Physiotherapy and Physical Education 3(2): 190-195.

14. Muruguvalavan V, Jayanthi V (2019) Effect of surya namaskar on body mass index, systolic and diastolic blood pressure among obese working women. International Journal of Yogic, Human Movement and Sports Sciences 4(1): 976-977. 

(C) (i) $\begin{aligned} & \text { Commons Attribution 4.0 License } \\ & \text { COI:10.19080/JYP.2019.07.555730 }\end{aligned}$
Your next submission with Juniper Publishers will reach you the below assets

- Quality Editorial service

- Swift Peer Review

- Reprints availability

- E-prints Service

- Manuscript Podcast for convenient understanding

- Global attainment for your research

- Manuscript accessibility in different formats

( Pdf, E-pub, Full Text, Audio)

- Unceasing customer service Track the below URL for one-step submission https://juniperpublishers.com/online-submission.php 